\title{
LACAN, MERLEAU-PONTY, AND IRIGARAY: REFLECTIONS ON A SPECULAR DRAMA
}

MARTHA J. REINEKE

University of Northern Iowa

In this essay, I will examine primary themes of l'écriture feminine, as they are represented by one of the most provocative and articulate of the new French feminists: Luce Irigaray. As I review key aspects of Irigaray's feminist vision and explore its attractiveness as an alternative to the phallogocentrism of our present discourse, I will raise questions about Irigaray's own ability to displace and overturn phallogocentric discourse through l'écriture feminine. Much of my criticism is focused on a father of the new French feminism, Jacques Lacan, whose veiled presence in Irigaray's writing threatens to distort and to co-opt her aims.

As I entertain the philosophy of Merleau-Ponty as a constructive alternative to Lacan, I will suggest that MerleauPonty's anthropology and ontology are not mired in the same phallocentric paradigms of sexuality and desire through which I see Irigaray betrayed by Lacan, despite Irigaray's efforts to evade seduction. I will give special attention to Merleau-Ponty's imagery of embodied dialogue, as well as to his notions of "ficld-being" and the foundational reciprocity of being in which persons are individualized. I will argue that a feminist criticism of sex-dualism must rest finally upon its criticism of the patriarchal forgetfulness of Being, a forgetfulness that neither Lacan nor his French feminist daughter confronts adequately, and upon the recovery of an anthropology and ontology open to Being.

\section{Meaning and Gender}

The new French feminism arises in the wake of the contesting of logocentrism by the post-structuralist tradition. The post-structuralists question key presumptions that have guided Western thought: the transparency of speech, the representation of things by words, and the possibility of selfidentical meaning. According to the post-structuralists, as soon as there is meaning, there is difference. Indeed, meaning is a 
function of difference. The key metaphysical error of Western thought, on which the deconstructionists focus their attention, has been the assumption that Being is determined by beingthere, by presence. The tyranny of binary thought is the legacy of this metaphysical error: man/woman, culture/nature, good/evil are all subsumed in service to a metaphysics of identity and binary opposition. ${ }^{1}$ Deconstructionists, such as Derrida, have focused their indictment of Western metaphysics on the level of textual meaning and have attempted to show that the primacy of one meaning of a text is created by suppression of others. Lacan's contribution to this discussion, a contribution of inestimable significance to the new French feminists, is his consideration of a key question: is gender difference a paradigm for all conceptualizations of difference? When Lacan responds affirmatively and unites linguistic and psychoanalytic theories, ascribing the source of meaning to internalization of the Law-of-the-Father, he makes a move of central import both to the deconstructive tradition in general, and to feminist theorists in particular. When Lacan posits the creation of the Other, of difference at the heart of sexual and conceptual differentiation, he prescribes a set of stiff requirements for humans to function as social subjects. A linguistic register is the sole index of meaning. Moreover, because gender is the lived paradigm of the alterity of meaning, the price humans pay for entry into the realm of meaning and language is the submission of their sexuality to restrictions or laws of organization and exchange within a sexually differentiated group. ${ }^{2}$

A story by Lacan in his essay, "The Insistence of the Letter in the Unconscious," offers a gripping portrait of the role of gender in the creation of meaning.

A train arrives at a station. A little boy and a little girl, brother and sister, are seated in a compartment face to face next to the window through which the buildings along the station platform can be seen passing as the train pulls to a stop. "Look," says the

${ }^{1}$ Claire Duchen, Feminism in France: From May '68 to Mitterand (New York: Methuen Books, 1986), p. 74.

2Elissa D. Gelfand and Virginia Thorndike Holes, "A Topography of Difference," in French Feminist Criticism: Women, Language, Literature (New York: Garland Publishing Co., 1985), pp. xxi-xxii. 
brother, "we're at Ladics!"; "Idiot," replies his sister, "can't you see we're at Gentlemen!"3

In this story, each child is able to sce only one of the rest rooms. Their immediate situation depicts the metaphysics of representation: a word signifies a thing. Their confidence in their location, and in its meaning, marks the confidence of classic correspondence theories of truth. Yet the gendered roles of boy and girl in this story portend the subversion of this simple scene. Through the material given that they are seated on one side of the train compartment or the other, each child is placed in a structure and as such is unable to see that structure.

The full import of the story hinges on the revelation of the play of the signifier in the story. First, a girl sees "Gentlemen" and a boy sees "Ladies." Irrevocable otherness is embedded in meaning. Second, while a material given, some would say a biological given, can be read in this story, this cannot be by attribution of maleness or femaleness in one-to-one correspondence to boy and girl. Rather, biological differences are of import only insofar as they insert the subject into the play of the signifier.4 According to Lacan, each child in the story, and each of us, so far as we live this story, must function in relation to an arbitrary and thus absolute boundary between the two realms of Ladies and Gentlemen, a boundary installed irrevocably upon our horizon through the advent of the signifier. Writes Lacan, "For these children, Ladies and Gentlemen will be henceforth two countries towards which each of their souls will strive on divergent wings, and between which a truce will be the more impossible since they are actually the same country and neither can compromise on its own superiority without detracting from the glory of the other."5

Lacan, who displays the special significance of revisionist psychoanalysis for the post-structuralist tradition and provides feminist theory with a most telling portrait of the parameters of patriarchal discourse, makes a point of crucial

3Jacques Lacan, Écrits, trans. Alan Sheridan (New York: W.W. Norton \& Co., Inc., 1977), p. 152.

'Jane Gallop, The Daughter's Seduction: Feminism and Psychoanalysis (Ithaca: Cornell University Press, 1982), p. 10.

5Lacan, Écrits, p. 152. 
significance: the path to meaning lies not with biological or material pre-givens. Rather meaning is constituted by a preexisting signifying chain, that culture by which one is "held in train," and in which one finds oneself always, already, placed prior to any arrival at the station of life. "We are all sitting on one side of the compartment or the other: we are all subject to the blindness imposed by our seats in the compartment;" 6 there is no other way of being on the signifying chain/train.

Lacan's structural drama introduces two themes: Desire and Law. Desire, mirrored in the boy's "Look, we're at Ladies," is the index of identity, of sameness, of fusion with the Real. The boy's concrete attachment, interrupted by the girl's call for an alternative recognition, "Gentlemen," introduces the Law of the signifier into the conversation. Though the law is introduced by the girl in Lacan's story, the play of the signifier thus introduced is phallic. Awareness of difference and alienation, the possibility of substitutive self-representation through naming, is, in the broader Oedipus drama from which Lacan's train station story takes its impetus, the Father's name (nom) which says "no" (non) to unitary meaning. The momentum of the story, linked with the word-of-the-Father at odds with the boy's image, posits the drive of Desire. A threat, not entirely veiled in the story, is that recognition will be sought at the other's expense. If necessary, the other will be annihilated in the struggle for validation of a unitary belief system. In an otherwise charming story, a difficult choice is offered: one learns difference, prerequisite for identity, by alienation into language and rules or one fails to evolve an identity adequate to social functioning at all. ${ }^{7}$

Yet, for feminists such as Irigaray, behind any female's choice lurks a grimmer threat than that noted by Lacan. The train of the signifier marks the female as irreducibly other. There is no woman, except she who is excluded by the nature of words. At the same time, because it is she who ushers in the acceptance of Law, the male, a nonetheless-divided subject, is supported by the phallus, an abstract signifier that becomes concretized by the penis. In other words, as the language of Desire sets into play efforts by which boy and girl struggle to

6allop, The Daughter's Seduction, pp. 11-12.

${ }^{7}$ Ellie Ragland-Sullivan, Jacques Lacan and the Philosophy of Psychoanalysis, (Urbana: University of Illinois Press, 1986), p. 273. 
Desire sets into play efforts by which boy and girl struggle to reflectively outdo each other, the boy has an advantage: he sees an identity of the signifier and signified registered by his own body and the phallic signifier. ${ }^{8}$ The history of patriarchy is the legacy of this power-play. Irigaray's criticism of Lacan focuses upon his inattention to this move. Lacan's inattention, she thinks, short-circuits a thorough-going deconstruction of Freud. Differrance--the deferral of masculine and feminine difference in the overturning of binary discourse-is subsumed under difference. Thus, in Lacanian theory woman is but a plane mirror who ensures the identity of man. She exists, not in the displacement of difference by différance, but only as a reflection of man himself. 9

\section{Irigaray's Criticism of the Lacanian Occult}

Of course, Lacanians can defend Lacan against Irigaray. They may suggest that Irigaray mistakes the descriptive, analytic function of Lacan's work for a prescriptive function and that she reads him substantively, rather than structurally. ${ }^{10}$ Even so, I submit that Lacanians oversimplify Irigaray's intent. Her criticism of Lacan draws him from the shadows of his stories, of which the story I have summarized is but one, to focus on his role as their author. Irigaray cites a confusion of the substantive with the structural that cannot be ignored. This confusion, she rightly argues, is not hers, but Lacan's. Lacan is blinded by a phallocentric investment in his own chain of signifiers. Irigaray traces Lacan's error to his privileging of sight over other senses. Oculocentrism supports and unifies

${ }^{8}$ Jacques Lacan, "The Meaning of the Phallus," trans. Alan Sheridan in Feminine Sexuality: Jacques Lacan and the École Freudienne eds. Juliet Mitchell and Jacqueline Rose (New York: W.W. Norton \& Co., 1985), p. 83. I note also Jane Gallop's Reading Lacan (New York: Cornell University Press, 1985), pp. 133-156. Gallop argues persuasively for the identity of penis/phallus in Lacan's work. She locates hermeneutic potential in a pun. The unconscious castration complex functions as a knot ("Meaning of the Phallus," p. 75). In French, "knot" is "noeud," a crude term for "penis."

${ }^{9}$ Hules, "A Topography of Difference," pp. xxvi-xxvii.

${ }^{10}$ Ragland-Sullivan, Jacques Lacan and the Philosophy of Psychoanalysis, p. 273. 
phallocentric theory. ${ }^{11}$ For Lacan, Irigaray argues, the materiality of sexual difference is obliterated by the Idea of sex. The riddle of sexual difference occulted, phallocentric metaphysics triumphs in the face of blind disregard.

Lacan's theory of the occult hinges upon the dream of symmetry. "Symmetry" means "to appropriate two things to like measure." When the feminine is judged by the standard of the masculine, the female is viewed as gap and lack. There is only absence in the male's sight of female genitalia: there is no symmetry, nothing of like measure. Irigaray writes,

Within this logic, the predominance of the visual ... is particularly foreign to female eroticism. Woman takes pleasure more from touching than from looking, and her entry into a dominant scopic economy signifies, again, her consignment to passivity: she is to be the beautiful object of contemplation. While her body finds itself thus eroticized ... her sexual organ represents the horror of nothing to see. A defect in this systematics of representation and desire. A 'hole' in its scoptophilic lens. ${ }^{12}$

For Irigaray, the optical error centers on the absence of form in the female sexual organ. The oneness of form that privileges phallomorphism cannot see that female sexuality is not formed. "Woman has sex organs more or less everywhere. She finds pleasure almost anywhere .... the geography of her pleasure is far more diversified, more multiple in its differences, more complex, more subtle, than is commonly imagined--in an imaginary rather too narrowly focused on sameness." 13

Thus, Irigaray initiates her reader into the play of "this sex which is not one." Female eroticism may be invisible to the optical theorists. After all, Lacan asks, as did Freud, "What do women want?" Even so, female eroticism is lived as multiform. Woman's alternative economy is not reducible to identity. Hence, woman falls outside the Lacanian economy which posits the mirror play of identity--either one or none-as

"Gallop, The Daughter's Seduction, p. 58.

${ }^{12}$ Luce Irigaray, "This Sex Which Is Not One," in This Sex Which is Not One trans. Catherine Porter with Carolyn Burke (Ithaca: Cornell University Press, 1985), p. 26.

13Irigaray, "This Sex," p. 28. 
the founding dynamic of signification. Female eroticism is an economy of nearness, of nearness "so pronounced that it makes all discrimination of identity, and thus all forms of property, impossible." Woman's pleasure is "so near that she cannot have it, nor have herself." 14

Irigaray confounds her critics who decry the "literalism" in her reading of the fathers of psychoanalysis, for she understands clearly the primacy of the linguistic register. In an interview titled "The Power of Discourse and the Subordination of the Feminine,"15 Irigaray speaks succinctly of the deconstructive path taken by l'écriture feminine. Her psychoanalytic reading of the specular economy is an interpretation of the linguistic register. Irigaray issues a call to listen to procedures of repression, to the "structuration of language that shores up its representations, and to examine the "operation of the 'grammar' of each figure of discourse."16 But for Irigaray, this examination of grammar opens out on its silences, for only there is a discourse of the female sex operative.

Irigaray's appeal to silence is an appeal to différance. Différance is experienced first in women's deliberate assumption of the feminine role, ${ }^{17}$ which converts a form of subordination into an affirmation and begins a process of subversion. As an interim strategy for dealing with the realm of discourse in which the speaking subject is posited as masculine, the deliberate assumption of feminine style enables women to uncover the mechanism by which they are exploited. Moreover, like Alice's voyages of exploration in Through the Looking Glass, women's journey of retraversal unveils the feminine as elsewhere. ${ }^{18}$

The "elsewhereness" of woman is necessarily linked with silence, for this is the "price" paid for withdrawal from the specular economy, from the phallic discourse that equates the silence of elsewhere with the absence of the phallus. Even so,

${ }^{14}$ Irigaray, "This Sex," p. 31.

${ }^{15}$ Irigaray, "The Power of Discourse and the Subordination of the Feminine," in This Sex Which Is Not One, pp. 68-86.

${ }^{16}$ Irigaray, "Power of Discourse," p. 75.

${ }^{17}$ Irigaray, "Power of Discourse," p. 76.

${ }^{18}$ Carolyn Burke, "Irigaray Through the Looking Glass," in Feminist Studies 7, No. 2 (Summer, 1981), p. 296. 
the elsewhere of feminine pleasure is lived, Irigaray writes, in "the crossing back through the mirror that subtends all speculation." Irigrary rightly acknowledges the dangers of her subversive discourse:

For to speak of or about woman may always boil down to, or be understood as, a recuperation of the feminine within a logic that maintains it in repression, censorship, nonrecognition. ${ }^{19}$

For this reason, she experiences feminine discourse as the offering of a new theory of woman, neither as subject nor as object, but rather as a "jamming of the theoretical machinery itself." ${ }^{20}$ L'écriture feminine--tactile, fluid, explosive of form and idea-cannot be upheld as a thesis. At a space in the feminine, at that break in the jammed machinery of theory, is différance.

Irigaray's efforts to liberate women from sexual objectification with a feminine jouissance that counters the phallic organization of sexuality are creative and inspiring. Her l'écriture feminine that presages women's shattering entry into history, as women's bodies are brought to speech from the silence of the repressed, offers poetic inspiration to women's emancipating goals. Even so, Irigaray's attempted subversion of the linguistic register, expressed by the decentered and displaced eroticism of the female body whose dual labia are emblematic of the sex which is not a sex, risks failure. True, Irigaray never claims usefulness for her theory. Its importance lies in its very nondirectiveness. Even so, Irigaray's "jamming" of the theoretical machinery of phallogocentrism brings to our ears the ever persistent clanking of the phallic discourse to which we still must attend.

When Irigaray invokes the rhythms of the body, she only extends the sphere of existent speech-she does not invent a new one. 21 The terrain of what can be expressed is enlarged, but the structure of that terrain is not altered. The reversal of value undertaken by l'écriture feminine remains caught in the

${ }^{19}$ Irigaray, "Power of Discourse," p. 78.

${ }^{20}$ Irigaray, "Power of Discourse," p. 78.

${ }^{21}$ Beverley Brown and Parveen Adams, "The Feminine Body and Feminist Politics," in m/f 3 (1979), p. 37. 
polarity of the specular economy. Irigaray's discourse does not depart from male-female opposition but participates in it.

Lacan's voice, speaking through the machinery of phallic discourse, reminds us that omniscience before the signifying chain will always, already, escape us. Jane Gallop sums up the problem for all feminists:

To date, the feminist efforts to understand and struggle against the cultural constructs of male-dominated society would have the subject consider as illusory the entire structure which makes the realms of Gentlemen and Ladies appear defined and absolute. ... That effort would place the feminist as observer in some sort of floating position outside the structure, a position of omniscience. Such positioning ignores the subject's need to place himself within the signifying chain in order to be any place at all. ${ }^{22}$

Because the social order itself is internalized as difference and language, it is not an external order to be overthrown. Thus, the Lacanian critics of Irigaray do speak a truth: the phallic pattern of discourse she would subvert does not operate at the conscious level where we might master it by exposing it as an ideology. Rather, its roots in the unconscious, indeed its constitution of the unconscious, mean that we always come too late to the scene to know what we ought to believe. ${ }^{23}$ Despite the brilliance of Irigaray's criticism, it falls prey to a form of binary thought. Irigaray's own blind spot, the blind spot endemic to the signifying chain on which we always, already find ourselves, misses the pattern of presence/absence, the vestiges of the occult, that cling to her own theory.

If we are to challenge Lacan, it cannot be by absenting ourselves from his discourse. Only by staying with him and working through him will it be possible to exchange a problematic omniscience for a glimpse or intimation of différance that has eluded l'écriture feminine.

22Gallop, The Daughter's Seduction, p. 12.

${ }^{23}$ I allude to a "perceptual faith" and embodied rootedness of perception. See Maurice Merleau-Ponty, The Visible and the Invisible trans. Alphonso Lingis (Evanston: Northwestern University Press, 1968), pp. 28 ff. 
III. The Play of the Specular Image: Lacan and MerleauPonty

I turn to the work of Merleau-Ponty in search of tools for deconstructing Lacan. My attention turns to a paradigm that marks the theories of both: the specular image. Both MerleauPonty and Lacan were fascinated by Wallon's study of infants' reactions to their images in a mirror. That, for both, Wallon's research became a subject for their own writing is not particularly surprising. However, that mirror-theory, indebted to Wallon, became virtually the "organizing paradigm" for their reflections on ontology, is remarkable. Moreover, for both Lacan and Merleau-Ponty, the philosophical legacy of Saussure framed their reactions to and understanding of the process of human development recorded by Wallon. Both Merleau-Ponty and Lacan were led by Saussure's influence to place their work on the specular theory within the context of a linguistic register, or a history of discourse. In comparing Merleau-Ponty's and Lacan's work, I hope to glimpse the displacement of phallogocentric discourse that might presage différance.

For both Merleau-Ponty and Lacan, the specular image serves as a founding metaphor for philosophical anthropology. Central to the anthropologies of both Merleau-Ponty and Lacan is the claim that perception of others is made comprehensible only if one supposes that psychogenesis begins in a state in which "the child is unaware of him/herself and the other as different beings." 24 This claim is founded upon a careful examination of a break in the process of human identitycreation, marked in an infant's stages of development at six months, between pre-specular and specular phases. In the prespecular world, there is no I-Other differentiation. Beginning observations of otherness focus not upon others, but upon partothers: feet, mouth, hands. Extroceptic perception is missing and the absence or presence of mother or father is impressed polymorphously upon an infant, as a sense of incompleteness. At this precommunicative stage, which could be called one of pre-recognition, an "undifferentiated group life" excludes ego-

${ }^{24}$ Maurice Merleau-Ponty, "The Child's Relations with Others," The Primacy of Perception, ed. James M. Edie (Evanston: Northwestern University Press, 1964), p. 119. 
awareness. ${ }^{25}$ The transition from undifferentiated life to difference functions to close one's body in upon itself, to disclose insularity of self and, correlatively, that of others.

At six months the specular phase beings. The stage is set for a crucial weaving of part into whole: the infant, looking in the mirror, smiles at his parent. ${ }^{26}$ At this moment, the parent speaks to the child. The child appears surprised and turns towards the voice. What knowledge is carried in this surprise? At this first stage in the specular drama, the parent's image takes on an existence separate from, though inferior to, the parent. ${ }^{27}$ Gradually, the child is able to distinguish, regularly and systematically, the image of the parent he sees in the mirror from his actual parent. The child's own awareness of his specular image comes later. At first, the child seems to see his specular image as a sort of double: he may kiss his image very ceremoniously or appear to play with it. But, as the child approaches twelve through eighteen months in age, he begins to deprive the specular image of its quasi-reality. The child does seem fascinated by the image, but the strongly felt reality of the image ceases to be a source of confusion: by means of the image in the mirror the child becomes capable of assuming the role of spectator of himself. Acquiring the specular image as specular image, the child passes from introceptive me to visual me, from the introceptive me to the specular $1 .^{28}$

Merleau-Ponty comments expressly on his agreement with Lacan about the significance of this "rite" of passage. He affirms Lacan's accurate gauging of the importance of this transitional moment in the life of the child. At the moment that the image of oneself makes possible, for the first time, a knowledge of self, one is alienated. Merleau-Ponty writes of this lesson which is of such decisive importance to human development:

I am no longer what I felt myself, immediately, to be; I am that image of myself that is offered by the mirror. ... I am 'captured,

25 Merleau-Ponty, "The Child's Relations wih Others," p. 119.

${ }^{26}$ For both Lacan and Merleau-Ponty, the child is a "he." Interestingly, Merleau-Ponty maintains the Father of Wallon's research; Lacan substitutes a Mother in the role of specular parent.

27 Merleau-Ponty, "The Child's Relations with Others," p. 129.

${ }^{28}$ Merleau-Ponty, "The Child's Relations with Others," p. 136. 
caught up' by my spacial image. ... In this sense I am torn from myself, and the image in the mirror prepares me for another still more serious alienation, which will be the alienation by others. ${ }^{29}$

For both Merleau-Ponty and Lacan, specular theory identifies the working of alienation that is inevitable in the human species. Specular theory marks the moment in which a conflict between the me felt by myself and the me seen by myself or by others is initiated. For both, acquisition of the specular image bears not so much on relations of understanding--an epistemological claim--as upon relations of being--an ontological claim. With grim observations that recall the Hegelian master/slave dialectic, Merleau-Ponty and Lacan each note that this alienation of the immediate me, its 'confiscation' for the benefit of the me that is visible in the mirror, already outlines what will be the confiscation of the subject by the others who look at me. ${ }^{30}$

Having shared stories to this point, Lacan and MerleauPonty diverge from each other as their analysis of the specular process continues. The importance of this divergence for my feminist project cannot be underestimated. Lacan, I will argue, moves on in forgetfulness of Being, to embrace phallogocentric discourse. In contrast, Merleau-Ponty's continued reflections bear intimations of an alternative discourse, one open to the recovery of an anthropology and ontology open to Being and to différance.

\section{A. Lacan: Specular Tyranny}

For Lacan, the central figure in the specular drama is the mother. Syncretism of the child with his mother marks the absence of psychic separation from (M)other, ${ }^{31}$ and a resulting incapacity to submit to a reality principle: the Law of nameof-the-Father. During the mirror stage, the infant wants to possess the (M)other because she provides an object of constancy and continuity that does not reside within. The lesson of the specular process is that this ideal of unity with (M)other is an

${ }^{29}$ Merleau-Ponty, "The Child's Relations with Others," p. 136.

30Merleau-Ponty, "The Child's Relations with Others," p. 137.

${ }^{31}$ Ragland-Sullivan, Jacques Lacan and the Philosophy of Psychoanalysis, pp. 26-29. 
illusion. The child experiences the full ambiguity of human behavior: a nonpeaceful coexistence with the specular moi through which self-awareness is given only as one is both divided from the (M)other and is forced to verify oneself through others. As the mirror stage ends, (M)other is repressed as the primordial pivot of Desire. She acts a mediator of Law, as one who introduces naming, language, through which alienation is both structured and recognized. The phallic signifier appears as a third term between mother and child, announcing the passage from nature to culture. The child's separation from the mother is traumatic castration. Yet even as the phallus marks difference/separation, it grants the capacity for speech: a capacity to symbolize absence which is the necessary mechanism for the survival of the pain of individuation. 32

According to Lacan, the mirror drama is reenacted throughout life as all humans seek and demand recognition from the Other. Gripped by desire of/for/by the Other(A), humans are driven to recreate psychic feelings of wholeness, jouissance, that characterize the prespecular stage of humans. Even so, the space between the moi--that nonverbal agent of specularity who experiences others as gaze even as it takes everything in with its own gaze--and the Other(A) widens, ${ }^{33}$ leading Lacan to describe Desire as the dérive de la jouissance. Dérive, a word used for the wake left by a boat in the water, gives way to an image of humans who, cut loose from their moorings and adrift in the world, can trace the experience of wholeness only to a wake. Rocked in the wake of Desire, they never recoup that sense of unity that precedes their lifejourneys across the water. ${ }^{34}$

Instead, introduced and maintained by language, a phallic injunction to separation pushes the child into the adult world in which Desire is displaced. In wanting to be the Other, human infants are subjugated by the Other's Desire, from which they must later find distance through displacements, if individuation is to be achieved. Adult psychic "freedom," measured in the work of psychoanalysis, lies in pinpointing this alien Desire. At best only partial recognition is possible.

\footnotetext{
${ }^{32}$ Ragland-Sullivan, pp. 55-56.

${ }^{33}$ Ragland-Sullivan, pp. 76-77.

${ }^{34}$ Ragland-Sullivan, p. 75.
} 
Any specular relation is one of narcissistic exclusion. The relation between analyst and analysand is no exception: two moi's try to objectify each other..$^{35}$ The war of the moi's, as a struggle between humans for omnipotence, puts humanity at risk. Yet, for Lacan, the lesson of psychoanalysis is that the moi's will for self survival, which consumes all in the drive for unity or self-destructs under the tyranny of the Other's gaze, is checked, and in a life-sustaining manner, by the Name-of-theFather which neutralizes the Master and Slave in all of us. "In this sense, the phallic superego saves the individual from psychosis, and the society from genocide, while also imposing tyranny and alienation on being. ${ }^{136}$

The name-of-the-Father is introduced as a saving grace. Even as Lacan identifies the entry of the Father in terms of an Oedipal drama and talks of the separation from unity with (M)other as castration, for Lacan the verbal capacity to symbolize absence, attributed to the Father's "nom and non" becomes the key intentional mechanism for surviving the trauma of unending otherness.

The war of the moi's is, finally, a gendered war. Without the male, the human female, identified in the signifying chain as lack, risks psychosis or ontological death. In partnering with man she attains value: she enjoys status within the social discourse that founds her identity against dissolution. Without the female, the human male threatens the destruction of others in his will to power. Man's desire for woman means that she functions as supplement to his own Imagined lack. Man makes love to complete himself. Woman is the catalyst in his psychic drama. Man's Imaginary fantasy guards the world against the victory of the powers of a death-driven ontology. ${ }^{37}$

Lacan's specular theory is one of our more exact portraits of patriarchy. That for Lacan the specular relation founds human identity, that for Lacan the specular relation always entails narcissistic exclusion, marks the Lacanian study of human identity as a most memorable study of phallogocentrism. The creation of masculine identity, as mirrored, is self-creation, to the exclusion of otherness. Différance eludes man.

\footnotetext{
${ }^{35}$ Ragland-Sullivan, p. 84.

${ }^{36}$ Ragland-Sullivan, p. 58.

${ }^{37}$ Ragland-Sullivan, p. 292-293.
} 
B. A Gestural Dialogue: Merleau-Ponty's Ontology

Merleau-Ponty's divergence from Lacan in his interpretation of the process of human development bears intimations of an alternative discourse, which, to the extent that feminism can partake of it, opens onto a recovery of nonphallogocentric Being and of différance. He emphasizes, as Lacan does not, the continuation of a corporeal condition, traced to the mirror stage, that leads us to feel, in the presence of a mirror, that we are finding something of ourselves. ${ }^{38}$ The lesson of the specular theory is not, for Merleau-Ponty, primarily visual, but rather tactual: children actually perceive themselves as being in two distinct places. ${ }^{39}$ Ubiquity of self promises the presence of others.

Merleau-Ponty dissents also from Wallon, for whom instruction in the specular teaches the child, through a synthesis of intellection, that the image he sees is not him. Merleau-Ponty, in contrast, sees the specular instruction less in terms of self and more in terms of others: the mirror shows the child what others see of him. He asks that we "consider the relation with others not only as one of the contents of our experience but as an actual structure in its own right. 40 While Wallon focuses on intellection, partakes of the philosophy of symmetry, and appears preoccupied with the problem of identity, Merleau-Ponty bypasses him to examine the ontological import of the specular instruction on other terms. For Merleau-Ponty, since image-reflection is unstable, the operations that constitute it "involve not only the intelligence proper, but, rather, all the individual's relations with others."41 The ubiquity of the body, both present in the mirror and present where felt tactually, marks as fundamental a living relation with others. As he focuses on this relational structure, Merleau-Ponty writes that "this magic belief, which at first gives the specular image the value not of a simple reflection ... . but rather of a double of oneself . . . re-forms itself in the emotional makeup of the adult." 42 For him, the lesson of

${ }^{38}$ Merleau-Ponty, "The Child's Relations with Others," p. 138.

${ }^{39}$ Merleau-Ponty, "The Child's Relations with Others," p. 139.

40 Merleau-Ponty, "The Child's Relations with Others," p. 140.

${ }^{41}$ Merleau-Ponty, "The Child's Relations with Others," p. 140.

${ }^{42}$ Merleau-Ponty, "The Child's Relations with Others," p. 138. 
the specular image truly has ontological measure, and in a fundamentally embodied manner. A mutuality of recognition is presaged, or prefigured, in the early specular drama.

Merlcau-Ponty goes on to examine more closcly the syncretic sociability, or field-being, that he thinks is not outrun by the child as it develops a sense of individual identity. Wallon's studies of jealousy and sympathy in the child offer crucial insight into Merleau-Ponty's theory of syncretic sociability. Moreover, because I believe that Wallon's study of jealousy corresponds with Lacan's typology of desire, just as Wallon's study of sympathy corresponds with Merleau-Ponty's typology of love, comparison of Merleau-Ponty and Lacan, via Wallon and in light of their receptive approaches to syncretic sociability, offers constructive possibilities for the thesis I have been elaborating in this essay.

Jealousy, for a child, manifests the failure of a child to isolate or affirm his own life in distinction from that of another. Having nothing of his own, the jealous child defines himself "entirely in relation to others and by the lack of what others have."43 Citing an example of jealousy in the adult, Merleau-Ponty notes that a man's rivalry with another man for the attention of a woman-a classic drama of jealousy-shows the jealous man to be one who lives not only by his own experiences, but also in assuming the life of the other. The jealous man knows not how to act, except as a spectator possessed by the action of the rival. This leads Merleau-Ponty to conclude that, in jealousy, there is always an element of homosexuality..$^{44}$

What then of sympathy? Just as jealousy is primarily a specular phenomenon, sympathy is primarily postural. Sympathy appears in the child on the foundation of mimesis. It is part of the attitudinal posture whereby I assume the gestures, conducts, and ways of doing things of those whom I confront. Wallon speaks of a kind of "postural impregnation" that founds the gestures of imitation. Sympathy emerges from this: "I live in the facial expressions of the other, as I feel him living in mine. It is a manifestation of what we have called, in other terms, the system 'me-and-other." ${ }^{145}$

${ }^{43}$ Merleau-Ponty, "The Child's Relations with Others," p. 143.

44Merleau-Ponty, "The Child's Relations with Others," p. 144.

${ }^{45}$ Merleau-Ponty, "The Child's Relations with Others," p. 146. 
For both Merleau-Ponty and Lacan, the crisis that ushers in the post-specular age and presages human maturation to adulthood marks the end of syncretic sociability: me-andother fusion. What are the legacies of the twin dramas of jealousy and sympathy in adulthood? In light of my thesis, jealousy is sustained in adult life as paradigmatic behavior under the conditions of patriarchy or under the rule of a phallic, specular economy criticized by Irigaray. As such, jealousy marks phallogocentric discourse as discourse that distorts possibilities for a postural, embodied discourse. Possessed by a dream of symmetry, those in the grip of jealousy squander dialogical possibilities, are blind to différance, and err as they attempt to ascribe all meaning either to "malebeing" or to "female-being." Analyses indebted to MerleauPonty suggest another scenario: we may ascribe jealousy to a specular economy in which a battle of moi's besets field-being, in forgetfulness of ontological potential.

If jealousy, seen in the child Wallon studies, is not outrun by the adult but resurfaces as part of a Lacanian specular tyranny of desire in adult life, what then of sympathy? Sympathy is extended also to the adult life. Significantly, it is MerleauPonty and not Lacan who appropriates sympathy as a paradigmatic possibility for adult life. For Merleau-Ponty, the continuation of the child's postural impregnation with the other in sympathy with that other is found again in the adult experience of love.

At this point, I catch a glimpse of an alternative to the oculocentric ontology criticized by Irigaray. Yet, even as I do, the voice of Lacan persists, raising suspicions in my mind. Is not sympathy, in the adult human, pathological? Does not sympathy fold under the consuming gaze of the other, for whom even sympathy is translated, in the adult, into the battle of two moi's who ever try to objectify each other? Is not selflessness, in the adult, a prescription for death of self? Is not Lacan's scenario, which subsumes all to the control of the Law, the only scenario for adult life with which we can live?

The answer to all of these questions is "no," not the "no" of the Father's law, but the "no" of the risk-taker who affirms more in her love than she knows. The risk is not the same as that recognized by Lacan: the risk of entrapment by the other. Although Merleau-Ponty does recognize the risk of a kind of love that ensnares or traps others because it never has enough 
proofs, for Merleau-Ponty another form of risk is possible for adult love. Adult love, for Merleau-Ponty, can affirm the promise of syncretic sociability, non-specularly: in the generosity of praxis. ${ }^{46}$ For Merleau-Ponty, the life-journey reaches toward fullness, not as humans are rocked in the desolate wake of desire, not as humans look backward toward fusion with a mother-shore whose safe banks they can never again attain, but in forward-moving praxis.

Central to Merleau-Ponty's vision is the foundational reciprocity of Being that is proved as it is lived out as real possibility in adult human lives. The relevance of his vision for feminism cannot be underestimated. Like Irigaray, Merleau-Ponty founds his ontology in embodied being. Unlike her, Merleau-Ponty escapes the vestiges of the economy of the occult. Where the binary opposition of masculine/feminine powered by the remnants of the patriarchal omniscient vision has persisted in Irigaray's work, Merleau-Ponty's anthropology resists naming the reciprocity of being that founds human discourse in terms of man-being and woman-being. Rather, for Merleau-Ponty, field-being is differentiated in a process of being-in-coexistence-with-another. ${ }^{47}$ His anthropology is not closed in upon the individual. Instead, it suggests the possibility of a world defined in terms of fundamentally intersubjective structures. The world arises as a response to the touch and gesture of another. The focus is not upon a dual reality of two existent individuals whose mutual recognition the philosopher of the specular strives to effect, but upon the reciprocity of being/Being in which persons are individualized. ${ }^{48}$ In this encounter there is reciprocal humanization: a dialogue of field-being. Merleau-Ponty's vision intimates différance: because dialogue is missed if man and woman are approached as individual monologues of being, for Merleau-Ponty woman and man as such do not exist. Who

46Merleau-Ponty, "The Child's Relations with Others," p. 155.

${ }^{47}$ Merleau-Ponty, "The Child's Relations with Others," p. 140 See also Maurice Merleau-Ponty, "The Body in Its Sexual Being," in Phenomenology of Perception trans. Colin Smith (London: Routledge and Kegan Paul, 1962), pp. 154-174.

${ }^{48}$ Abel Jeanniere, The Anthropology of Sex trans. Julie Kernan (New York: Harper \& Row, 1964), p. 128. 
they are is created and carried in the praxis of embodied conversation.

For feminist theory, the transcendent possibilities of encounter Merleau-Ponty cites hold much promise. The fundamental expressivity of the body displays a structural potential for a communion that may never be exhausted. The passage from syncretic sociability of childhood to adulthood, as a passage from implicit to explicit sociability, is itself the journey of Being. The promotion of being to expression and the articulation of human presence in the reciprocity of mutual recognition are at once the promotion of Being to expression. 